\title{
Use of Blackboard Application in Language Teaching: Language Teachers' Perceptions at KAU
}

\author{
Hanan Ismail Kutubkhanah Alsaied \\ English Language Institute, Women's Main Campus, King Abdulaziz University, Jeddah, Saudi Arabia \\ E-mail: hananismailk@gmail.com
}

Received: 17-05-2016

Accepted: 24-07-2016

Published: 01-11-2016 doi:10.7575/aiac.ijalel.v.5n.6p.43

Advance Access Published: September 2016

URL: http://dx.doi.org/10.7575/aiac.ijalel.v.5n.6p.43

\begin{abstract}
The popularity of learning management systems (LMSs) in ELT has been enhanced due to extensive availability of technological infrastructure for educational institutions. Previous studies reveal the fact that adoption of new technologies is always supported by the positive insights of the practitioners. Current study is based on the same ideology and aims to explore EFL teachers' perceptions of the constructive application of blackboard technology in English Language Teaching. In order to investigate the teachers' perceptions on the use of blackboard system, the researcher and 40 Language teachers from a major English Language Institute -King Abdulaziz Universty (KAU)participated in this study; a survey questionnaire was used as the research tool. Overall study reflects a positive trend towards the use of blackboard system in language teaching at ELI - KAU. Majority of the participants confirmed that the use of Blackboard provides a structured e-learning platform that facilitates the development of a healthy learnercentered arena in ELT. Additionally, the present study aims to highlight the pedagogical implication of blackboard system as a source of blended learning.
\end{abstract}

Keywords: LMS; ELI; KAU; blended learning; ELT; EFL

\section{Introduction}

Due to its' flexible accessibility, pervasiveness, and ease of use, many institutions in kingdom of Saudi Arabia (KSA) have implemented blackboard as a component of LMS. The latest online teaching trends are motivating learners through participating in discussion forums, sharing course content, online assignment submission and receiving prompt feedback from the instructors and fellow students. At the same time, teachers' varying perceptions about the use of blackboard in teaching English as a foreign language (EFL) may play a vital role in developing the students' interest towards this online learning tool. Teachers' perceptions exert influence on their mode of adapting technology in classrooms. Based on current studies, since most of the teachers are still using technology as a search engine for teaching material, sending assignment notifications, sharing course content and practice sessions, technology has not been utilized to its maximum advantage as an effective teaching tool to foster effective learning (Ertmer \& OttenbreitLeftwich, 2010; Koc, 2013). A survey results that was conducted in 2007 on the use of technology by teachers in the United States has revealed the fact that the most frequently used mode of technology in classrooms is for administrative purposes instead of pedagogical tasks. At present, in order to enhance students' interest and abilities and to focus their learning styles, the most important thing is to change the mode of use for technology, mainly the Blackboard and Moodle to be used for instructional tasks to endorse student-centered learning. Bearing in mind the teachers role in bringing this change from administrative use to pedagogical approach, the current study aims to explore teachers' perceptions on Blackboard applications in English as a foreign language (EFL) environment.

\subsection{Learning Management Systems (LMSs) in the field of ELT}

The extensive use of the Internet has boosted the implementation of learning management systems (LMSs) in many educational institutions. The reason behind this are the easy access to the technological infrastructure and frequent use of internet (Levy \& Stockwell, 2006; West, Waddoups, \& Graham, 2007). A research has indicated that web-based learning environment has provided a huge amount of learning sources for various types of learners. This opportunity has enhanced the interactive learning environments among students, teachers and course materials, and also provide extensive cross-cultural collective learning prospects. Such web-based learning system provides an arena of interaction among the students and teachers where they can communicate with each other anywhere and anytime for their own needs and share the ideas (Cavus, 2007; Levy \& Stockwell, 2006). The most popular LMS currently used in most of the institutions are Blackboard, WebCT, Moodle, LAMS, and SAKAI. Some researchers (Chang, 2008; West, Waddoups, \& Graham, 2007) believe that Blackboard, which is founded in 1997, is a commercially licensed LMS, and is one of the most popular vendible LMSs frequently used in higher education institutions. The frequently used tools in Blackboard have the capability to switch options as per teachers' teaching and learners' learning needs (DeNeui \& Dodge, 2006). The Blackboard offers a highly interactive medium of learning that can be modified to meet the students' individual 
learning needs (Levine \& Sun, 2003). Extensively used LMS, mainly the Blackboard, may inspire and help modify the selection and development of online resources and also help improve the traditional teaching practices (Coates, 2007).

\subsection{Technology Integration in ELT and Teachers' Perceptions}

Even after having a massive digital exposure in this technological era, teachers' acceptance and user friendly handling for e-learning tools has varying levels. What is more, there is a slow rate of transition for instructional practices from traditional methods to technological techniques. Considering the fact that there are yet many teachers who consider technology as a supplementary teaching tool rather than viewing it as an essential component of successful teachinglearning process, there exist a few teachers who still fear that online interaction between teacher and students might replace the face-to-face interaction (Walker, 2004). Research also revealed that technology is used globally in education field, but these methods are yet not fully equipped to facilitate student learning since instead of enhancing the student-centered teaching approach, they simply support lecture-based instruction medium (Cuban, Kirkpatrick, \& Peck; 2001; Law-less \& Pellegrino, 2007; Zemelman, Daniels, \& Hyde, 2005). This is the need of time that we should find more creative ways for using this innovative mode of teaching to improve teaching standards and learning capabilities (West, Waddoups, \& Graham, 2007). There is a group of teachers who are not well motivated and can't time frame their training to use this technology effectively and become expert users of online systems and improve this pedagogic mode. Teachers need to be persuaded about the importance of LMSs in education field; they should be convinced with the frequent use of e-tools. The reason for this is that effective teaching is directly proportional to the effective technology use. A surprising fact is that high levels of effective use of technology in education is yet not achieved even in technologically advanced countries (Kozma, 2003; Mueller, Wood, Willoughby, Ross, \& Specht, 2008; Smeets, 2005; Tondeur, van Braak, \& Valcke, 2007).

These facts reveal that teachers' perceptions on technology integration have a significant impact on the constructive integration of technology to language learning and teaching. As per findings by Kagan (1992), teachers' beliefs provide a basis for the teaching methodology and are directly linked to the congruent style of teaching in that particular scenario. Hereafter, a shift to technology based teaching style requires a vital change to teachers' beliefs about the use of technology. Furthermore, as indicated by Kane, Sandretto, \& Heath (2002), such teaching beliefs play a major role in developing the institutional practice and policy. Findings of any research that is based on teachers' perceptions conclude that the interrelationships between beliefs and actions provide a basis for new practical trends (e.g., Albion, 1999; Albion \& Ertmer, 2002; Ertmer, Gopalakrishnan, \& Rosse, 2001). As technology has turned into an integral component of the modern day life, considering its consequences and developing user friendly trends are essential skills in today's work ethics. It is not essential that implication of new technologies in teaching trends would cause a shift in pedagogical practice; as an alternative, sometimes it may support the existing pedagogical basis and outlook (Zurita \& Ryberg, 2005). This is also indicated by Ertmer (2005) that there should be an obviously noticeable link between technology and the curriculum. In addition, because real technology integration is only possible when it is effectively applied to the curriculum and to the students' learning, teachers who are exposed to this situation should have a clear insight. Dockstader (1999) strengthened this fact by stating that the models of technology integration to the curriculum and student learning prove that the teacher is an vital part of the integration of technology. Yet, successful use of computer technology needs an instructional shift to constructivist teaching (Strommen \& Lincoln, 1992; Jonassen, Peck, \& Wilson, 1999) that provides a base for student-centered learning (Pedersen \& Liu, 2003; Sandholtz, Ringstaff, \& Dwyer, 1997).

\subsection{Teachers' Perceptions on the use of Blackboard for Blended learning;}

The current research will present a quantitative analysis of EFL teachers' perceptions about the process of adoption of the Blackboard applications. This is quite evident from the concept of Computer-assisted Language Learning (CALL) that multiple computer soft wares can be easily used for communication and conveying of meaning in the target language. A skilled use of CALL can change the future of language teacher education because language teachers have a key role in this field. Teachers can select the tools as per their teaching needs and determine how CALL applications should be exposed to the language learners and how learners can benefit from them. As stated by Warschauer \& Healey (1998), both computers and the Internet are regarded as the most significant items for the field of language learning.

The main purpose of this study is to explore the teachers' perceptions on Blackboard applications in EFL. Previously conducted studies on teachers' perceptions in EFL indicated that investigating the relationship between teachers' and students' beliefs about teaching and learning techniques always provide a basis for developing new teaching methodology and improve style of teaching to fit into a particular situation (Ahmad \& Aziz, 2009). In addition, A latest research by Drewelow (2013) enforces to have further exploration of teachers' perceptions and understandings about their roles and teaching practices inside a hybrid foreign language classroom since this gives a clear clue to the implications of training trends. These findings validate the requirement of further studies on teachers' beliefs about LMS applications, especially Blackboard, in an EFL context as this may lead to effective endeavors in the upcoming era of language teaching and learning.

\section{Methodology}

\subsection{Participants}

Fourty language teachers at the ELI - King Abdulaziz Universty Saudi Arabia were selected participated in the present study. They are all teaching English at the ELI in different levels. The participants' age varies between 25- 50, with the average age being 32. Almost all of the participants are non-native speakers of English; 25 Arabs, 10 Asians, 5 Africans 
with a teaching experience ranging between 2-25years. Their minimum blackboard experience is 3 years and all are certified blackboard teachers. Survey was distributed through the Google survey shared procedures and responses were collected online in a given time frame.

Table 1. Demographic data of the participants

\begin{tabular}{lllllll}
\hline & Range & Number & Range & Number & Range & Number \\
\hline Age (Years) & $25-30$ & 15 & $30-40$ & 20 & $40-50$ & 5 \\
Experience (Years & Less than 5 years & 10 & $5-15$ & 25 & $15-25$ & 5 \\
\hline
\end{tabular}

\subsection{Assessment Methods}

A survey questionnaire was used as the data collection instrument as this is a reliable source of gathering data and the repetitive response from the participants to the same questions increases the reliability of the data collected (Munn $\&$ Drever, 1990). The Google online survey method was used and the survey form with two sections (demographic information of the participants and their perceptions towards blackboard) was constructed by the researcher which was given to the participants via email notification (Appendix A). The survey targeted at finding the perceptions of the participants on the use of Blackboard in the context of language learning at the ELI. The components of the survey reflected on the multiple aspects of the implementation of blackboard in language learning settings. Survey was constructed based on a 5-Point Likert-scale ranging from 1 (strongly disagree) to 5 (strongly agree). On the other hand, the scale for the negative statements was 1 (strongly agree) and 5 (strongly disagree). For any survey its' validity endurance is always important. In order to confirm the rationality of the survey, it was first piloted by 5 instructors at the ELI; their feedback helped to improve certain aspects of the selected questions. The reliability of the survey was also tested by requesting three senior assistant professors to have a critical overview of the questions' validity and structural output. In the light of their suggestions, 4 statements were modified.

\section{Results and Discussion}

\subsection{Analysis of the Survey}

In order to indicate the means, standard deviation, and frequency of the participants' responses to the survey, having a descriptive statistics is highly important. To address the set research point, "How do teachers perceive the use of blackboard for language teaching?" descriptive statistics have been calculated. The descriptive statistics for the positive points shown by the survey are reflected in Table 2; the means, standard deviation, and frequency for the negative elements reflected by the survey are indicated in Table 3 given below.

Table 2. Descriptive statistics of the positive points of the survey

\begin{tabular}{|c|c|c|c|c|c|c|c|c|}
\hline \multicolumn{2}{|c|}{ Statement } & \multicolumn{7}{|l|}{$\%$} \\
\hline & & \multirow{3}{*}{$\begin{array}{l}\text { SA } \\
25\end{array}$} & \multirow{3}{*}{$\begin{array}{l}\text { A } \\
62.5\end{array}$} & \multirow{3}{*}{$\begin{array}{l}\mathrm{N} \\
10\end{array}$} & \multirow[b]{2}{*}{$\mathrm{D}$} & \multicolumn{2}{|c|}{ M } & SD \\
\hline & & & & & & SD & & \\
\hline 1 & BB facilitates the users. & & & & 2.50 & 0 & 4.4 & 0.6 \\
\hline 2 & $\begin{array}{l}\text { BB is an interactive way to maintain a friendly teacher- } \\
\text { student relation. }\end{array}$ & 22.5 & 57.5 & 15 & 5.00 & 0 & 4.0 & 1 \\
\hline 3 & BB turns language teaching process easier & 37.5 & 45 & 12.5 & 5.00 & 0 & 4.1 & 0.9 \\
\hline 4 & BB supports my style of language teaching & 17.5 & 52.5 & 12.5 & 12.50 & 5 & 3.5 & 1.5 \\
\hline 5 & $\begin{array}{l}\text { BB helps to link the pedagogical principles to technology } \\
\text { integration. }\end{array}$ & 27.5 & 50 & 15 & 5.00 & 2.5 & 3.9 & 1.1 \\
\hline 6 & $\begin{array}{l}\text { BB is widely appreciated because it is a structured e- } \\
\text { learning platform. }\end{array}$ & 35 & 45 & 15 & 5.00 & 0 & 4.0 & 1 \\
\hline 7 & $\begin{array}{l}\text { BB provides sufficient support to manage the teaching aid } \\
\text { documents online in a DL course. }\end{array}$ & 45 & 47.5 & 5 & 2.50 & 0 & 4.6 & 0.4 \\
\hline 8 & $\begin{array}{l}\text { My positive perception of BB changed as I have gained } \\
\text { more online teaching experience. }\end{array}$ & 40 & 50 & 10 & 0.00 & 0 & 4.5 & 0.5 \\
\hline 9 & BB helps students improve their language competencies & 25 & 52.5 & 17.5 & 2.50 & 2.5 & 3.9 & 1.1 \\
\hline 10 & $\begin{array}{l}\text { Rate of the use of provided teaching materials by the } \\
\text { students is quite satisfactory. }\end{array}$ & 32.5 & 50 & 12.5 & 5.00 & 0 & 4.1 & 0.9 \\
\hline 11 & $\begin{array}{l}\text { BB provides a good online source for foreign language } \\
\text { learning. }\end{array}$ & 45 & 45 & 10 & 0.00 & 0 & 4.5 & 0.5 \\
\hline
\end{tabular}




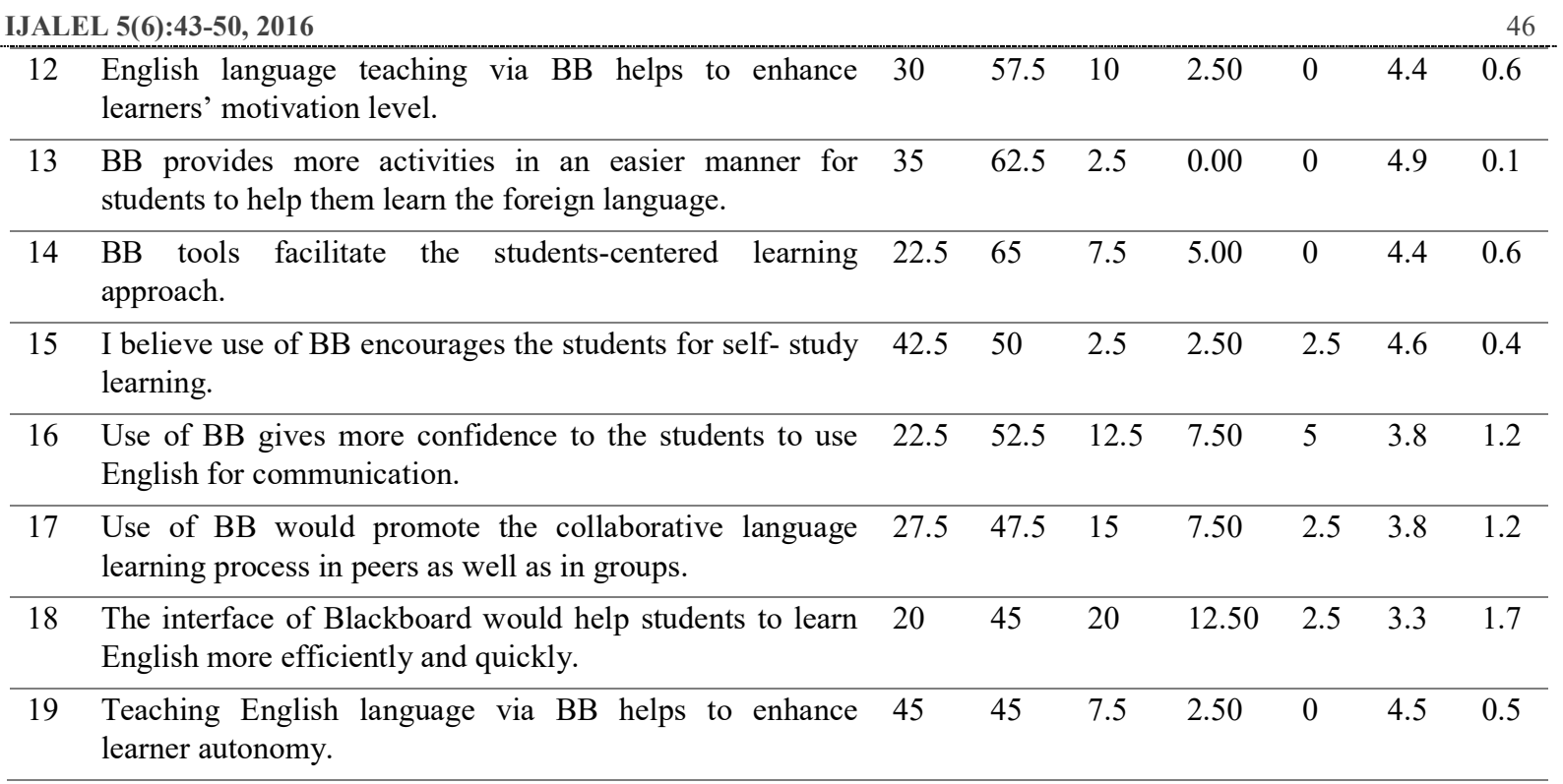

The above shown results from the descriptive data analysis indicate that the participants have overall positive perceptions towards the application of Blackboard for Language teaching process. The model of explaining means by Siti Rahaya and Salbiah's (1996) was used by the researcher in order to explain the level of means for the found data (Table 4).

As shown by the data in table 2, there exists a significantly positive attitude towards the positive statements on the given survey. Figures indicate that 13 out of 19 positive statements have clearly obtained high/ very high scale except those 6 items with moderately high scale of means. There is one statement (BB provides more activities in an easier manner for students to help them learn the foreign language) that is 4.9 which is rated as very high, 17 statements obtained between 3.4-4.6, which are rated as high, and one item rated as moderate, obtaining 3.3.The total means of the 19 statements is 3.78 , indicating that the overall mean of the positive statements is high.

Table 3. Descriptive statistics of the negative points of the survey

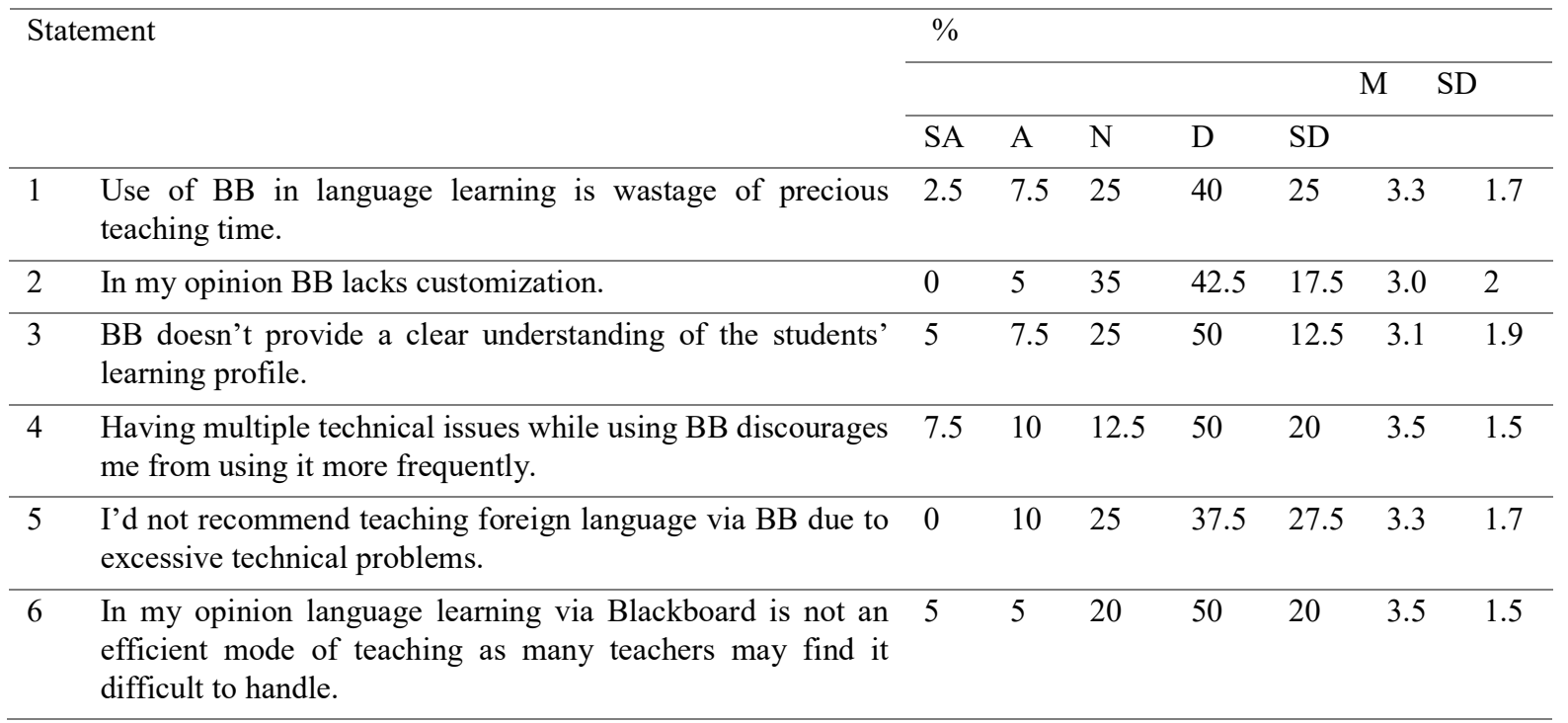

Concerning the negative statements, mentioned in Table 3, there is a downfall of mean value frequencies than the positive points reflected in Table 2. The means of the negative statements are comparatively lesser than those in the positive statements. Besides that, many teachers have given a not applicable response. As indicated in Table 3, the mean varies between the scale 'moderate' and 'low'. None of the negative statements scaled high or very high, all of them scaled as moderate. The overall mean for the negative statements is 2.8 , demonstrating that the overall mean of the negative statements is moderate. 
Table 4. Mean Score category breakdown Model (adopted from Siti Rahaya and Salbiah (1996)

\begin{tabular}{ll}
\hline Mean values & Level \\
\hline $1.0-1.8$ & Very low \\
\hline $1.8-2.6$ & Low \\
\hline $2.6-3.4$ & Moderate \\
\hline $3.4-4.2$ & High \\
\hline $4.2-5.0$ & Very high \\
\hline
\end{tabular}

\section{Conclusion}

Findings of the study reflect that majority of the English Language teachers have positive perceptions towards the application of the Blackboard in language teaching process. This is a dynamic finding that 9 points on this survey have scored the highest mean values (Above 4.21). Another worthwhile point is that the item with the highest mean value is 4.9. This shows the teachers' complete confidence on the use of activities in an easier manner for the students to help them learn the foreign language. It also indicates that majority of the teachers possess positive pedagogical approach regarding the integration of technology in language teaching. As mentioned by previous studies (Albion \& Ertmer, 2002; Ertmer, Gopalakrishnan, \& Rosse, 2001), such a positive approach plays a significant role towards the use of new technology in language teaching. A vast majority of teachers think that blackboard helps link the pedagogical principles to technology integration and also they agree to the fact that English language teaching via BB helps to enhance learners' motivation level. As mentioned by some previous findings, instructors' technological and pedagogical understandings help to successfully implement web-based teaching-learning activities (Comas-Quinn, 2011; Hauck \& Stickler, 2006). Many teachers have widely appreciated the use of blackboard because it is a structured e-learning platform that provides support to the learners to improve their language learning in multiple competencies. They admit that it helps to improve the teacher-student relationship in a course and facilitates the process of teaching English and makes it more successful.

A vast majority of the participants have shown their easy to handle approach towards the blackboard tools operation, that determines that Blackboard is a user friendly system. However, some teachers showed their reservations about the technical problems while using blackboard and they were concerned about the wastage of precious teaching time while dealing with such challenges. Most of the participants have not given any significant importance to the idea that some teachers may find it difficult to handle or Blackboard lacks customization. Beside, this is a positive approach that most teachers have found Blackboard as a supportive system that helps to deliver interactive lessons by allowing the students to interact with teachers without the fear of time zone and physical attendance.

Henceforth, the proposed research question for this study "What are the perceptions of teachers for the adoption of the Blackboard applications in the context of English language teaching?" could be concluded that majority of the language teachers have found it a supportive and valuable tool that enhances the level of students' learning and promotes learner autonomy.

\subsection{Suggestions}

The findings of this study show the common perceptions of language teachers about Blackboard applications. Having done such a study on a set of participants, with variable demographic details in a different context, will definitely be a good idea. Having such a study done for a different set of participants with variant demographic details would strengthen the obtained results. Blackboard is the type of LMS that was focused as a study tool for the current study; Nevertheless, the researcher would suggest using some other tools with varying pedagogical perspective in order to get a comparative analysis of the findings. The findings of this study have indicated the positive perceptions of the language teachers towards the use of blackboard regarding blended learning and learner autonomy. The researcher would suggest conducting a parallel type of study to analyze the perceptions of the technical staff and the faculty managers in order to enhance the effectiveness of the study.

\section{References}

Ahmad, F., \& Aziz, J. (2009). Students' perception of the teachers' teaching of literature communicating and understanding through the eyes of audience. European Journal of Social Sciences, 7(3), 17-26.

Albion, P. (1999). Self-efficacy beliefs as an indicator of teachers' preparedness for teaching with technology. In Proceedings of the 10th International Conference of the Society for Information Technology \& Teacher Education (SITE 1999) (pp. 1602-1608). Association for the Advancement of Computing in Education (AACE).

Albion, P. R., \& Ertmer, P. A. (2002). Beyond the foundations: The role of vision and belief in teachers' preparation for integration of technology. TechTrends, 46(5), 34-38.

Cavus, N. (2007). Assessing the success rate of students using a leaning management system together with a collaborative tool in Web-Base teaching of programming languages. Journal of Educational Computing Research, 36(3), 301-321. 
Chang, C. (2008). Faculty perceptions and utilization of a learning management system in higher education (Unpublished doctoral dissertation). Ohio University, 2008.

Coates, H. (2007). A model of online and general campus-based student engagement. Assessment \& Evaluation in Higher Education, 32(2), 121-141.

Comas-Quinn, A. (2011). Learning to teach online or learning to become an online teacher: An exploration of teachers' experiences in a blended learning course. ReCALL Journal, 23(3), 218-232.

Cuban, L., Kirkpatrick, H., \& Peck, C. (2001). High access and low use of technologies in high school classrooms: Explaining an apparent paradox. American Educational Research Journal, 38(4), 813-834.

DeNeui, D. L., \& Dodge, T. L. (2006). Asynchronous learning networks and student outcomes: The utility of online learning components in hybrid courses. Journal of Instructional Psychology, 33(4), 256-259.

Dockstader, J. (1999). Teachers of the 21 st century know the what, why, and how of technology integration. THE journal, 26(6), 73-74.

Drewelow, I. (2013). Exploring graduate teaching assistants' perspectives on their roles in a foreign language hybrid course. System, 41(4), 1006-1022.

Ertmer, P. A. (2005). Teacher pedagogical beliefs: The final frontier in our quest for technology integration? Educational technology research and development, 53(4), 25-39.

Ertmer, P. A., Gopalakrishnan, S., \& Ross, E. M. (2001). Technology-Using Teachers. Journal of Research on Computing in Education, 33(5), 1-26.

Ertmer, P. A., \& Ottenbreit-Leftwich, A. T. (2010). Teacher technology change: How knowledge, confidence, beliefs, and culture intersect. Journal of research on Technology in Education, 42(3), 255-284.

Glaser, B., \& Strauss, A. (1999). The Discovery of Grounded Theory: Strategies for Qualitative. Research. London: Wiedenfeld and Nicholson.

Hauck, M., \& Stickler, U. (2006). What does it take to teach online? CALICO Journal, 23(3), 463-475.

Jonassen, D. H., Peck, K., \& Wilson, B. G. (1999). Learning with technology: A constructivist approach. Merrill/ Prentice-Hall: Upper Saddle River, NJ.

Kagan, D. M. (1992). Implications of research on teacher belief. Educational Psychologist, 27(1), 65-90.

Kane, R., Sandretto, S., \& Heath, C. (2002). Telling half the story: A critical review of research on the teaching beliefs and practices of university academics. Review of Educational Research, 72(2), 177-228.

Koc, M. (2013). Student teachers' conceptions of technology: A metaphor analysis. Computers \& Education, 68, 1-8.

Kozma, R. B. (2003). Technology and classroom practices: An international study. Journal of Research on Technology in Education, 36, 1-14.

Levine, A., \& Sun, J. C. (2003). Distributed education: Summary of a six-part series. Washington, DC: American Council on Education.

Levy, M., \& Stockwell, G. (2006). CALL dimensions: Options and issues in computer assisted language learning. Teaching English as a Second or Foreign Language, 11(2), 1-4.

Mueller, J., Wood, E., Willoughby, T., Ross, C., \& Specht, J. (2008). Identifying discriminating variables between teachers who fully integrate computers and teachers with limited integration. Computers \& Education, 51(4), 15231537.

Ottenbreit-Leftwich, A. T., Glazewski, K. D., Newby, T. J., \& Ertmer, P. A. (2010). Teacher value beliefs associated with using technology: Addressing professional and student needs. Computers \& Education, 55(3), 1321-1335.

Pedersen, S., \& Liu, M. (2003). Teachers' beliefs about issues in the implementation of a student-centered learning environment. Educational Technology Research and Development, 51(2), 57-76.

Sandholtz, J. H., Ringstaff, C., \& Dwyer, D. C. (1997). Teaching with technology: Creating student-centered Classrooms. New York: Teachers College Press.

Strommen, E. F., \& Lincoln, B. (1992). Constructivism, technology, and the future of classroom learning. Education and Urban Society, 24(4), 466-476.

Tondeur, J., Van Braak, J., \& Valcke, M. (2007). Curricula and the use of ICT in education: Two worlds apart? British Journal of Educational Technology, 38(6), 962-976.

Walker, G. (2004). Faculty intentions to use web-enhanced instructional components. Retrieved February 22, 2014, from http://home.hawaii.rr.com/gregaloha/Walker\%20Greg\%20 Dissertation.pdf

Warschauer, M. (1997). Computer-mediated collaborative learning: Theory and practice. The Modern Language Journal, 81(4), 470-481.

West, R. E., Waddoups, G., \& Graham, C. R. (2007). Understanding the experiences of instructors as they adopt a course management system. Educational Technology Research and Development, 55(1), 1-26. 
Zemelman, S., Daniels, H., \& Hyde, A. (2005). Best practice: Today's standards for teaching and learning in America's schools. Portsmouth, NH: Heinemann.

Zurita, L., \& Ryberg, T. (2005). Towards a collaborative approach of introducing e-learning in higher education institutions. How do university teachers conceive and react to transitions to e-learning? IFIP World.

\section{Appendix 1}

\section{Questionnaire}

Perceptions of Language Teachers on the use of blackboard in distance learning;

\section{Section A: Personal and background Information}

1. Name (optional):

2. Email Address:

3. Please choose your job title:
a. Teacher assistant
b. Lang. instructor
c. Lecturer
d. Assistant Professor

4. Please choose your age group:
a. $20-30$
b. $30-40$
c. $40-50$
d. 50 and above

5. Teaching experience (in years):
a. Less than 5 years
b. 5 to 10 years
c. 10 to 20 years
d. More than 20 years

6. Have you ever attended a formal training course on Blackboard Applications?
a. Yes
b. No

7. Have you received training in e-learning at your current job place?
a. Yes
b. No

8. Do you think further training on the usage of Blackboard can be useful?

Choose one of the following options.
a. Not at all
b. Small Increase
c. Significant Increase

9. What percentage $(\%)$ of your Distance learning course materials are on Blackboard?
a. $0-20$
b. $20-40$
c. $40-60$
d. $60-80$
e. $80-100$

\section{Section B:}

\section{Please read each statement and then circle one that best describes your perception:}

1. Blackboard facilitates the users.

Strongly Agree $\quad$ Agree Neutral Disagree $\quad$ Strongly Disagree

2. Blackboard is an interactive way to maintain a friendly teacher- student relation.

Strongly Agree $\quad$ Agree Neutral Disagree $\quad$ Strongly Disagree

3. Blackboard turns language teaching process easier.

$\begin{array}{llll}\text { Strongly Agree } & \text { Agree } & \text { Neutral } & \text { Disagree }\end{array}$

4. Blackboard supports my style of language teaching.

Strongly Agree Agree Neutral Disagree Strongly Disagree

5. Blackboard helps to link the pedagogical principles to technology integration.

Strongly Agree Agree Neutral Disagree Strongly Disagree

6. Use of BB in language learning is wastage of precious teaching time.

Strongly Agree Agree Neutral Disagree Strongly Disagree

7. In my opinion BB lacks customization.

$\begin{array}{llll}\text { Strongly Agree } & \text { Agree } & \text { Neutral } & \text { Disagree }\end{array}$ 
8. Blackboard doesn't provide a clear understanding of the students' learning profile.

Strongly Agree Agree $\quad$ Neutral Disagree $\quad$ Strongly Disagree

9. Having multiple technical issues while using BB discourages me from using it more frequently.

Strongly Agree Agree Neutral Disagree $\quad$ Strongly Disagree

10. Blackboard is widely appreciated because it is a structured e-learning platform.

$\begin{array}{lllll}\text { Strongly Agree } & \text { Agree } & \text { Neutral } & \text { Disagree } & \text { Strongly Disagree }\end{array}$

11. Blackboard provides sufficient support to manage the teaching aid documents online in a DL course.

Strongly Agree $\quad$ Agree $\quad$ Neutral Disagree $\quad$ Strongly Disagree

12. My positive perception of BB changed as I have gained more online teaching experience.

$\begin{array}{lllll}\text { Strongly Agree } & \text { Agree } & \text { Neutral } & \text { Disagree } & \text { Strongly Disagree }\end{array}$

13. Blackboard helps students improve their language competencies.

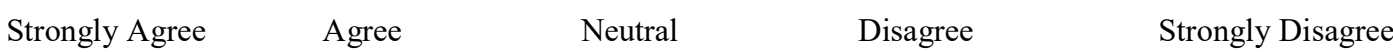

14. Rate of the use of provided teaching materials by the students is quite satisfactory.

Strongly Agree Agree Neutral Disagree $\quad$ Strongly Disagree

15. Blackboard provides a good online source for foreign language learning.

$\begin{array}{llll}\text { Strongly Agree } & \text { Agree } & \text { Neutral } & \text { Disagree }\end{array}$

16. English language teaching via Blackboard helps to enhance learners' motivation level.
Strongly Agree
Agree
Neutral
Disagree
Strongly Disagree

17. $\mathrm{BB}$ provides more activities in an easier manner for students to help them learn the foreign language.
Strongly Agree
Agree
Neutral
Disagree
Strongly Disagree

18. Blackboard tools facilitate the students-centered learning approach.

Strongly Agree Agree Neutral Disagree $\quad$ Strongly Disagree

19. I believe use of Blackboard encourages the students for self- study learning.

Strongly Agree Agree Neutral Disagree $\quad$ Strongly Disagree

20. Use of Blackboard gives more confidence to the students to use English for communication.

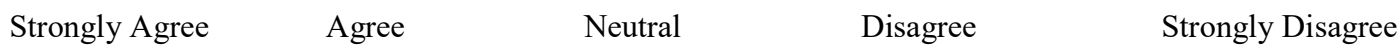

21. Use of BB would promote the collaborative language learning process in peers as well as in groups.

Strongly Agree Agree Neutral Disagree $\quad$ Strongly Disagree

22. The interface of Blackboard would help students to learn English more efficiently and quickly.

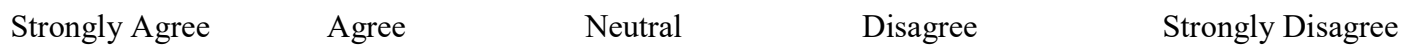

23. Teaching English language via BB helps to enhance learner autonomy.

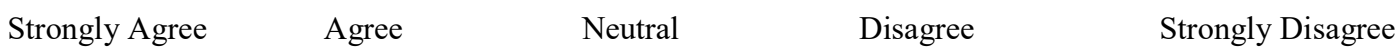

24. I'd not recommend teaching foreign language via BB due to excessive technical problems.

Strongly Agree Agree Neutral Disagree $\quad$ Strongly Disagree

25. Language learning via $\mathrm{BB}$ is not an efficient mode of teaching as many teachers find it difficult to handle.

$\begin{array}{llll}\text { Strongly Agree } & \text { Agree } & \text { Neutral } & \text { Disagree }\end{array}$ 